\title{
Feather hydrolysate as a promising nitrogen-rich fertilizer for greenhouse lettuce cultivation
}

\author{
Lisiane Sobucki ${ }^{1} \cdot{\text { Rodrigo Ferraz } \text { Ramos }^{1} \text { - Elci Gubiani }}^{2}$ - Gustavo Brunetto ${ }^{2}$ - Douglas Rodrigo Kaiser ${ }^{3}$. \\ Daniel Joner Daroit ${ }^{1}$
}

Received: 26 October 2018 / Accepted: 12 June 2019 / Published online: 19 June 2019

(c) The Author(s) 2019

\begin{abstract}
Purpose Poultry agro-industry generates huge amounts of solid wastes, such as poultry litter (PL) and feathers. Feathers, possessing a substantial amount of organic nitrogen, are mainly converted into feather meal (FM) through the hydrothermal process; however, microbial conversion into feather hydrolysates $(\mathrm{FH})$ is increasingly being focused on. Since waste management strategies include the use of organic wastes as soil fertilizer, PL, FM, and FH were evaluated as fertilizers for lettuce in comparison to urea.

Methods Lettuce seedlings were transplanted to soil pots containing FH, obtained through feathers' bioconversion by Bacillus sp. CL18, FM, PL, urea, and unfertilized controls. Partial chemical characterization of FH, FP, and PL was performed. Fertilization treatments were applied to reach $180 \mathrm{~kg} \mathrm{~N} / \mathrm{ha}$. Growth, dry biomass, and chlorophyll contents of lettuce were evaluated to indicate fertilizer performance.

Results After 60 days of greenhouse lettuce cultivation, leaves per plant were superior after FH treatment. Lettuce fertilized with urea and FH presented higher and similar foliar areas. FH treatment resulted in increased dry weight (DW) of leaves, which then decreased in the order urea $>\mathrm{FM}>\mathrm{MM} \sim$ controls $>$ PL. Dry weight of leaves and roots was 33\% and $64 \%$ higher with FH than with urea. Leaf total chlorophyll content was higher with FH, but similar to urea and FM. Lettuce growth was negatively affected by PL when compared to controls.

Conclusion FH, obtained from microbial processing of abundant and inexpensive feathers, could be a candidate N-rich fertilizer for lettuce cultivation.
\end{abstract}

Keywords Organic waste $\cdot$ Poultry litter $\cdot$ Feather meal $\cdot$ Feathers $\cdot$ Bioconversion $\cdot$ Hydrolysate

\section{Introduction}

Agricultural productivity is sustained by proper fertilization practices and management. Chemical and/or organic fertilizers are usually employed to achieve higher crop yields, and

Daniel Joner Daroit

djdaroit@gmail.com

1 Laboratório de Microbiologia, Universidade Federal da Fronteira Sul (UFFS), Campus Cerro Largo, Rua Jacob Reinaldo Haupenthal 1580, Cerro Largo, RS 97900-000, Brazil

2 Departamento de Solos, Centro de Ciências Rurais, Universidade Federal de Santa Maria (UFSM), Santa Maria, RS 97105-900, Brazil

3 Laboratório de Química e Fertilidade do Solo, Universidade Federal da Fronteira Sul (UFFS), Campus Cerro Largo, Cerro Largo, RS 97900-000, Brazil urea is the major synthetic nitrogen $(\mathrm{N})$ fertilizer employed globally. Organic fertilizers are recognized as alternatives to synthetic sources, also potentially contributing to increased soil quality from both agricultural and environmental perspectives. Animal manures, and composts obtained thereof, releasing $\mathrm{N}$ to soil through mineralization, are among the organic materials usually utilized as fertilizers (Sorathiya et al. 2014; Cantú et al. 2017). Several other organic wastes have been investigated as fertilizers and soil amendments, also considering that such practices represent potential approaches for waste management and recycling (Gaskell and Smith 2007; Alvarenga et al. 2015).

The poultry agro-industry generates enormous amounts of organic waste. Poultry litter, constituted of bedding material, excreta and spilled feed, is a major by-product from confined poultry rearing facilities. In Brazil, approximately 6.8 million $\mathrm{m}^{3}$ of poultry litter are generated annually and, 
considering its typical composition, poultry litter could be used as a nutrient source for plant growth (Rogeri et al. 2016). Feathers, composed primarily of refractory proteins (keratins), are abundantly generated during poultry processing for meat production. In fact, at least 1600 tons of waste feathers are generated on a daily basis in the Brazilian scenario (De Oliveira et al. 2016). Although feathers contain around $15 \%(\mathrm{w} / \mathrm{w})$ of $\mathrm{N}$, its recalcitrance results in slow rates of decomposition and $\mathrm{N}$ mineralization in soils, precluding its direct application as fertilizer (Thuriès et al. 2001).

Diverse processes have been investigated to transform feathers into more available $\mathrm{N}$ sources for agricultural use (Choi and Nelson 1996; Joardar and Rahman 2018; Mushtaq et al. 2019). For instance, hydrothermal processing is applied to destabilize the feathers structure and the resulting product, feather meal, is described as a potential N-rich soil amendment (Hadas and Kautsky 1994; Thuriès et al. 2001). Microbial processing is also considered as a suitable technology for feathers management, and the resulting protein hydrolysates might present an interesting potential for agricultural use (Paul et al. 2014; Kumawat et al. 2017).

Lettuce (Lactuca sativa L.) is extensively grown and one of the most consumed vegetables worldwide. In Brazil, lettuce is the main leafy vegetable crop, with approximately 35,000 ha of cultivated area. Although majority of the marketed lettuce is grown in the field, protected cultivation of lettuce is increasingly adopted, mainly due to diminished risks and the improved predictability and constancy of production (Sala and Costa 2012). Since N is one of the most important nutrients regarding commercial lettuce production, the present investigation aimed to evaluate poultry litter, feather meal and a microbial feather hydrolysate as fertilizers for greenhouse lettuce cultivation as compared to urea.

\section{Material and methods}

\section{By-products of poultry agro-industry}

Feather meal (FM) was from Kabsa S.A. (Brazil). Poultry litter (PL), consisting of wood shavings as bedding material and derived from a single broiler rearing cycle, was obtained from a local farm. After drying $\left(65^{\circ} \mathrm{C}\right)$ and milling, $\mathrm{PL}$ and $\mathrm{FM}$ were submitted to $\mathrm{HNO}_{3}-\mathrm{HClO}_{4}$ digestion. $\mathrm{Ca}, \mathrm{Cu}$, $\mathrm{Fe}, \mathrm{Mg}, \mathrm{Mn}$, and $\mathrm{Zn}$ contents were determined by atomic absorption spectrophotometry (AAnalyst 200, Perkin Elmer, USA), K through flame photometry (DM-62, Digimed, Brazil), and total $\mathrm{N}$ using a TOC-L total organic carbon analyzer (Shimadzu, Japan) equipped with a TNM-L unit. Chemical characterization is presented in Table 1.

Whole feathers, collected from a local slaughterhouse, were thoroughly washed with distilled water and dried at $50{ }^{\circ} \mathrm{C}$ until constant weight. Feathers were employed for the production of feather hydrolysates through microbial conversion.

\section{Production of feather hydrolysate}

Feathers bioconversion was performed through submerged cultivations using the keratinolytic bacterium Bacillus sp. CL18. Bacterial suspensions prepared in sterile saline were employed $(1 \mathrm{~mL})$ to inoculate Erlenmeyer flasks $(250 \mathrm{~mL})$ containing $50 \mathrm{~mL}$ of feather broth, composed of mineral medium (MM; $0.5 \mathrm{~g} / \mathrm{L} \mathrm{NaCl}, 0.3 \mathrm{~g} / \mathrm{L} \mathrm{K}_{2} \mathrm{HPO}_{4}, 0.4 \mathrm{~g} / \mathrm{L}$ $\left.\mathrm{KH}_{2} \mathrm{PO}_{4}\right)$ and chicken feathers $(30.0 \mathrm{~g} / \mathrm{L})$. Initial $\mathrm{pH}$ was adjusted to 7.5 before autoclaving (Sobucki et al. 2017).

Incubations were performed at $30{ }^{\circ} \mathrm{C}, 125 \mathrm{rpm}$, for 7 days. After this period the media were filtered, the filtrates were autoclaved $\left(121^{\circ} \mathrm{C}, 105 \mathrm{kPa}, 15 \mathrm{~min}\right)$ and centrifuged $(9500 \times g$ for $10 \mathrm{~min})$. Collected supernatants were employed as feather hydrolysate (FH). Partial chemical characterization of $\mathrm{FH}$, performed as described above, is presented in Table 1.

\section{Greenhouse lettuce cultivation}

Cultivations were conducted during April-June 2017 (Autumn in Southern hemisphere), in a polyethylene greenhouse located in the Rio Grande do Sul State (Brazil). Soil from this area (0-20 cm layer), a Red Ferralsol, was used as substrate for lettuce cultivations. The soil (0-20 cm layer) had the following physicochemical characteristics: clay, $561 \mathrm{~g} / \mathrm{kg}$; silt, $339 \mathrm{~g} / \mathrm{kg}$; sand,

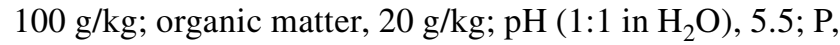
$15.7 \mathrm{mg} / \mathrm{dm}^{3} ; \mathrm{K}, 204.1 \mathrm{mg} / \mathrm{dm}^{3} ; \mathrm{Ca}, 7.2 \mathrm{cmol}_{\mathrm{c}} / \mathrm{dm}^{3} ; \mathrm{Mg}$, $3.4 \mathrm{cmol}_{\mathrm{c}} / \mathrm{dm}^{3} ; \mathrm{Cu}, 17.1 \mathrm{mg} / \mathrm{dm}^{3} ; \mathrm{Zn}, 4.0 \mathrm{mg} / \mathrm{dm}^{3}$; base saturation, $81.4 \%$; cation exchange capacity (CEC, $\mathrm{pH} 7$ ), $13.5 \mathrm{mEq} / 100 \mathrm{~g}$; effective CEC, $11.1 \mathrm{mEq} / 100 \mathrm{~g}$.

Plastic pots $(1 \mathrm{~kg})$ were filled with non-sterilized soil and then the different fertilization treatments were applied, namely PL, FM, FH, or urea (45\% N; Heringer ${ }^{\circledR}$, Brazil).

Table 1 Chemical composition of poultry litter, feather meal, and feather hydrolysate

\begin{tabular}{lrrr}
\hline Determination & $\begin{array}{l}\text { Poultry litter } \\
(\mathrm{PL})(\mathrm{mg} / \\
\mathrm{kg})\end{array}$ & $\begin{array}{l}\text { Feather meal } \\
(\mathrm{FM})(\mathrm{mg} / \mathrm{kg})\end{array}$ & $\begin{array}{l}\text { Feather hydro- } \\
\text { lysate }(\mathrm{FH}) \\
(\mathrm{mg} / \mathrm{L})\end{array}$ \\
\hline $\mathrm{Ca}$ & 991.44 & 3146.48 & 9.83 \\
$\mathrm{Cu}$ & 4.04 & 22.64 & 0.11 \\
$\mathrm{Fe}$ & 384.44 & 526.24 & 0.35 \\
$\mathrm{~K}$ & $11,616.00$ & $25,520.00$ & 250.00 \\
$\mathrm{Mg}$ & 1820.16 & 671.16 & 7.78 \\
$\mathrm{Mn}$ & 58.44 & 18.00 & 0.07 \\
$\mathrm{~N}$ & 2110.67 & $119,484.76$ & 1536.50 \\
$\mathrm{Zn}$ & 18.92 & 151.52 & 0.73 \\
\hline
\end{tabular}


In the Rio Grande do Sul State, $\mathrm{N}$ fertilization rates are recommended based on the soil organic matter content (CQFS-RS/SC 2016). For lettuce cultivation in soils with organic matter contents below $2.5 \%$, the fertilization treatments were thus incorporated into soil to reach $\mathrm{N}$ amounts equivalent to $180 \mathrm{~kg} \mathrm{~N} / \mathrm{ha}$ ( $180 \mathrm{mg} \mathrm{N} / \mathrm{kg}$ soil).

Soil pots treated with solid fertilizers (PL, FM, and urea) and control soil pots (without fertilization) received a volume of distilled water equivalent to the volume of applied FH. Soil pots receiving MM, a component for FH production, were also prepared, and the volume of applied MM was identical to that of FH added to soil pots. Equal volumes of liquid were ensured for all pots aiming to reach the soil field capacity.

To evaluate the effects of these treatments, soil pots were prepared in quintuplicates, with one plant/pot (Cozzolino et al. 2016; Yang et al. 2016). A six-leaf lettuce seedling (cultivar Stella) was transplanted to soil pots, which were randomly placed over $80 \mathrm{~cm}$ height benches inside the greenhouse. Cultivations were carried out for 60 days at ambient temperature under natural light. Irrigation was performed daily with distilled water.

\section{Lettuce vegetative growth parameters}

The number of leaves was periodically assessed for all lettuce plants during cultivation. At day 60, just before harvest, the chlorophyll content of lettuce leaves was measured using a SPAD-502 portable chlorophyll meter (Minolta, Japan). Three leaves/plant were selected, and two measures/leaf were performed. Average chlorophyll content (SPAD value) was then calculated per treatment. Following harvest, the dry weight (DW, g) of lettuce roots, stem and leaves was determined after drying at $65^{\circ} \mathrm{C}$ until constant weight. Average DW of roots, stems and leaves was then calculated for each treatment.

Leaf area was estimated for all lettuce plants using an indirect method (Castoldi et al. 2014). Fifteen leaf discs of the known area $\left(1.617 \mathrm{~cm}^{2} /\right.$ disc $)$ were collected per plant, constituting the leaf subsample area (SLA). Discs were subsequently dried at $65^{\circ} \mathrm{C}$ to obtain the leaf subsample dry weight (SDW). Along with the total DW of leaves per plant (TDW), the following equation was employed to calculate the plant leaf area (PLA; $\mathrm{cm}^{2} /$ plant): $\mathrm{PLA}=[(\mathrm{SLA} \times \mathrm{TDW}) / \mathrm{SDW}]$. Average PLA was then calculated for each fertilization treatment.

\section{Statistical analysis}

Obtained data were subjected to ANOVA (F test), and comparisons of means were performed through the Tukey's test at $95 \%$ confidence level.

\section{Results and discussion}

The vegetative growth parameters of greenhouse lettuce were assessed for FH, PL, FM, and MM treatments in comparison to urea, the most common commercial $\mathrm{N}$ fertilizer (Cantú et al. 2017). Leaf numbers were accompanied during the cultivation period (60 days) and, as early as the 18 th day, lettuce fertilized with FH displayed increased numbers in comparison to the other treatments (Fig. 1). This pattern was maintained throughout the cultivation period. Incorporation of FM and MM resulted in leaf numbers comparable to controls, whereas PL caused a strong negative effect on lettuce growth (Fig. 1).

Increased foliar area of lettuce, after 60 days of cultivation, was observed for urea, which was statistically similar to that achieved with FH. Control and FM treatments displayed intermediate results, whereas the lowest area was observed with PL fertilization (Fig. 2A). The DW of lettuce biomass was superior for the FH fertilization when compared to the other treatments. Specifically, the DW of lettuce leaves in the FH treatment was 33\% and $87 \%$ higher than urea and FM, respectively (Fig. 2B). The stem DW was also significantly higher for FH fertilization in comparison to the other treatments (Fig. 2C). For lettuce roots, $42 \%$ and $64 \%$ increase in DW were observed for the FH fertilization when compared to FM and urea, respectively (Fig. 2D). On the other hand, lettuce biomass was strongly and negatively affected by PL treatment (Fig. 2).

Analogously, FH produced by Bacillus amyloliquefaciens $6 \mathrm{~B}$ had a positive influence on mung bean germination, plant

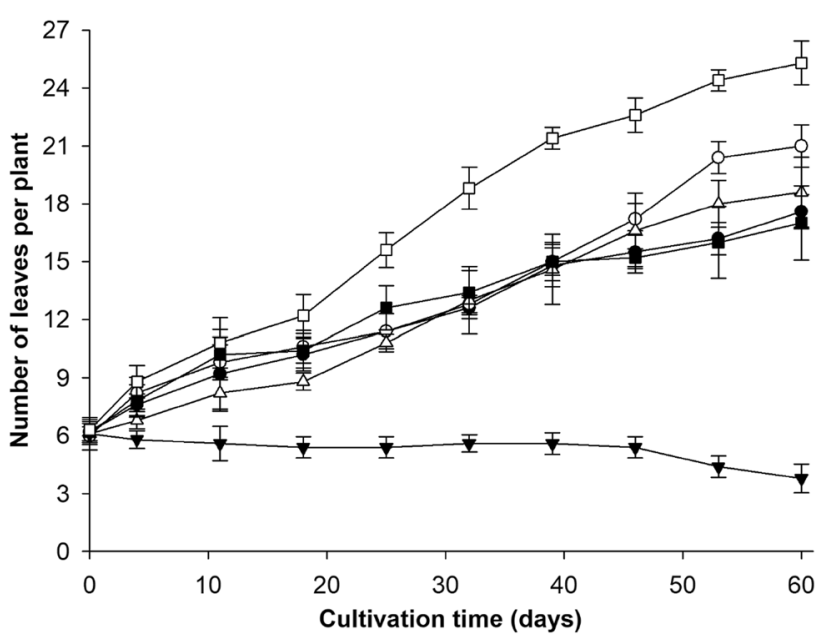

Fig. 1 Number of leaves of the lettuce plants submitted to different fertilization treatments, during 60 days of greenhouse cultivation. Treatments: poultry litter (black down-pointing triangle); control, without fertilization (black circle); mineral medium (black square); feather meal (white triangle); urea (white circle); feather hydrolysate (white square) 

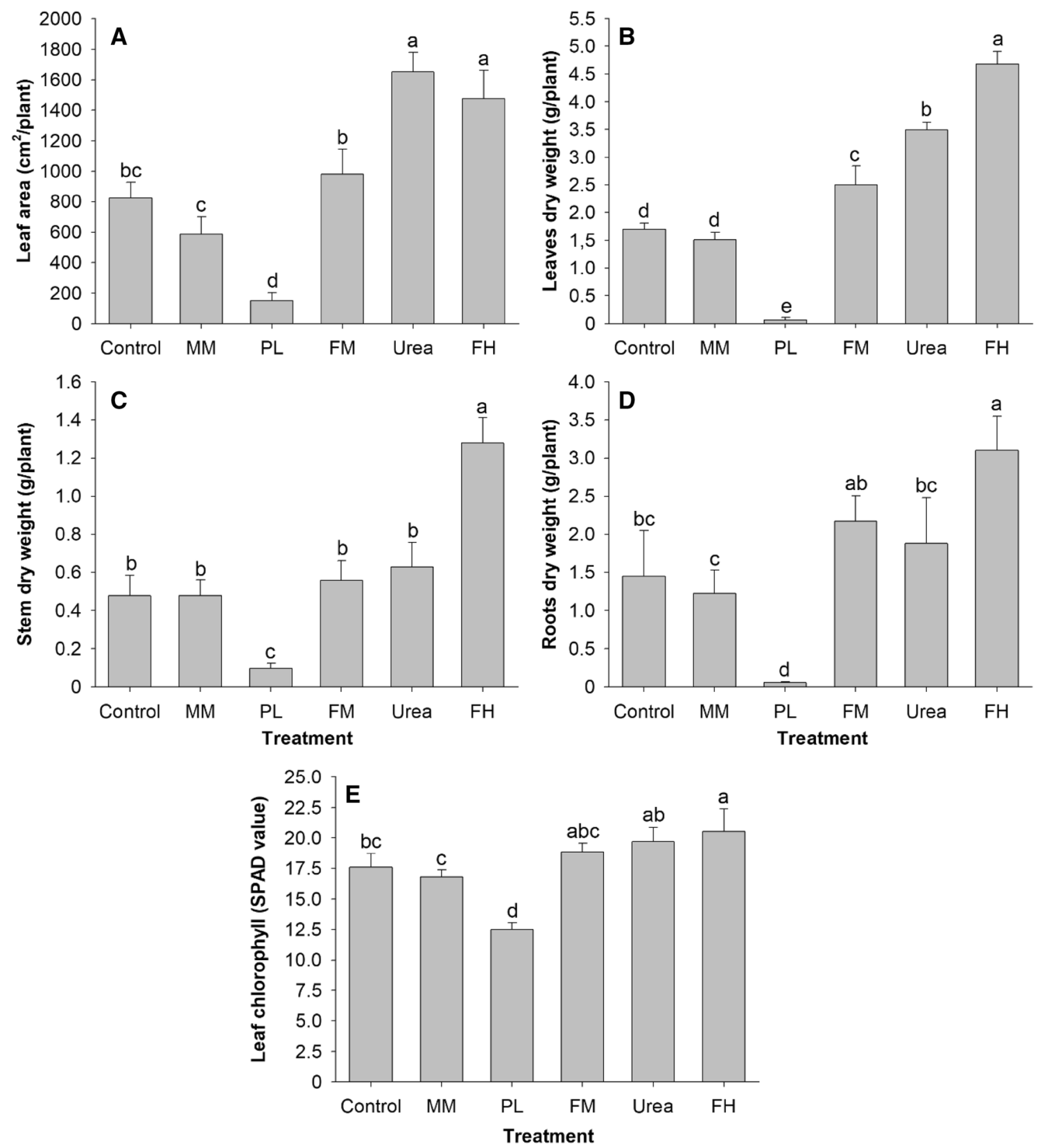

Fig. 2 Vegetative parameters of lettuce plants after 60 days of greenhouse cultivation with different fertilization treatments. Leaf area (A), leaves dry weight $(\mathrm{B})$, stem dry weight $(\mathrm{C})$, roots dry weight $(\mathrm{D})$, and leaf chlorophyll content (E). Abbreviations: MM: mineral medium;

height and biomass, and root length and biomass, when compared to unfertilized soil; furthermore, evaluated parameters were comparable to those employing reference fertilization (Bose et al. 2014). FH obtained with Bacillus pumilus KHS-1 was equivalent to a reference fertilizer in terms of growth, root DW and shoot DW of carrot and Chinese cabbage (Kim et al. 2005). Also, feather hydrolysates obtained through microbial conversion displayed promising results as fertilizers for wheat (Jain et al. 2016), rice (Tamreihao et al.
PL: poultry litter; FM: feather meal; FH: feather hydrolysate. Results are presented as mean \pm SEM. Means followed by the same letter, for each parameter, do not differ by Tukey's test $(p>0.05)$

2017), ryegrass (Gousterova et al. 2011), chickpea (Paul et al. 2013), and banana plants (Gurav and Jadhav 2013).

The low carbon-to-nitrogen (C:N) ratio of FH (around 1.6), along with peptides more accessible to microbial action, might allow rapid mineralization, making $\mathrm{N}$ available for plant absorption. Besides minerals, peptides and amino acids contained in protein hydrolysates could also be directly absorbed by the roots and then translocated to other plant tissues, acting as biostimulants. Protein hydrolysates might 
also indirectly enhance plant growth through microorganism-mediated soil processes (Colla et al. 2015). Ammonifying, nitrifying, $\mathrm{N}_{2}$ fixing, and P-solubilizing bacteria are among the beneficial microbial populations stimulated by FHs in soils (Paul et al. 2013; Bose et al. 2014; Jain et al. 2016).

Lettuce parameters tended to be higher in the FM treatment in comparison to unfertilized controls, particularly the DW of leaves (Fig. 2). FM incorporation into a peat compost substrate resulted in increased DW of tomato shoots, evaluated 35 days after transplanting, in comparison to controls without fertilization (Gagnon and Berrouard 1994). Addition of FM to soil at doses of 112, 168 and $225 \mathrm{~kg} \mathrm{~N} / \mathrm{ha}$ increased DW of lettuce biomass when compared to zero and $56 \mathrm{~kg} \mathrm{~N} /$ ha (Pereira et al. 2017).

In soil, FM is more prone to microbial attack than whole feathers. FM had $11.9 \% \mathrm{~N}$ (Table 1), nearly identical to the $12 \% \mathrm{~N}$ previously reported for FM (Gaskell and Smith 2007). Considering a C:N ratio of around 3.3, microbial decomposition could lead to net $\mathrm{N}$ mineralization (Thuriès et al. 2001). In this sense, cumulative $\mathrm{N}$ release from distinct FMs was 27-52\% after 11 weeks, although most $\mathrm{N}$ was released within 5 weeks (Choi and Nelson 1996). Hartz and Johnstone (2006) indicated that 50, 57, and 64\% of the organic $\mathrm{N}$ contained in FM were mineralized after 1, 2 , and 4 weeks of soil incubation at $25^{\circ} \mathrm{C}$. Nevertheless, the remaining organic $\mathrm{N}$ of FM might present a relative recalcitrance to microbial decomposition (Hadas and Kautsky 1994), resulting in a subsequent slower release of inorganic $\mathrm{N}$, that could only partially meet the $\mathrm{N}$ demands for lettuce growth (Fig. 2).

Therefore, the composition of organic materials directly influences their degradation and mineralization rates in soils which, in turn, affect nutrient availability for plant growth (Gaskell and Smith 2007). This is particularly important for plants with rapid growth and short vegetative cycles, such as lettuce. The negative results obtained in the PL treatment reinforce the significance of this concept (Figs. 1, 2).

Chemical characterization of PL samples $(n=165)$ from confined poultry rearing facilities located in the Rio Grande do Sul and the Santa Catarina States (Brazil) indicated an average $\mathrm{N}$ content of $2.2 \%(1.1-4.4 \%)$ and a $\mathrm{C}: \mathrm{N}$ ratio of 11.2 (9.2-18.1), suggesting the prompt release of $\mathrm{N}$ into soil, without microbial immobilization (Rogeri et al. 2016). Pelletized poultry manure $(2.6 \% \mathrm{~N})$ increased lettuce growth, when evaluated 65 days after seedling transplant, compared to unfertilized controls (Gunes et al. 2014). The $\mathrm{N}$ content of PL utilized as fertilizer in the current study was substantially lower (0.2\%; Table 1). Although soil pots received equal $\mathrm{N}$ amounts, the high C:N ratio of lignocellulosics from PL bedding material might have resulted in a net $\mathrm{N}$ immobilization, explaining the negative effects on lettuce growth (Gagnon and Berrouard 1994). Therefore, the high variability of PLs nutritional quality (Rogeri et al. 2016) should be considered when aiming its utilization as fertilizer.

The production of chlorophylls, fundamental pigments for plant photosynthetic processes, is highly dependent on $\mathrm{N}$ availability. Since leaf chlorophyll correlates with a plant's N status, which affects crop yield, chlorophyll contents might be employed as indicators of fertilizer performance (MuñozHuerta et al. 2013). A trend of higher chlorophyll content in lettuce leaves (SPAD values) was observed with FH fertilization; however, these values were statistically similar to lettuce fertilized with urea and FM (Fig. 2E). Conversely, FH resulted in significantly higher chlorophyll content when compared to controls, MM and PL.

Alkaline hydrolysates from tomato plants tended to increase the chlorophyll content of bean leaves, which was positively correlated with plant growth and productivity (Baglieri et al. 2014). Total chlorophyll of banana leaves increased due to FH fertilization in comparison to unfertilized controls, and the productivity of fruits was positively correlated with leaf chlorophyll content (Gurav and Jadhav 2013). Similarly, higher chlorophyll content of lettuce leaves in the FH treatment (Fig. 2E) was related to the increased lettuce biomass (Fig. 2B-D). However, PL fertilization resulted in poorer chlorophyll content, translated into diminished lettuce growth, reinforcing an $\mathrm{N}$ deficiency in the PL treatment.

\section{Conclusion}

Feather hydrolysates, obtained through microbial conversion of chicken feathers, increased growth and biomass yield of greenhouse-cultivated lettuce when compared to a reference fertilizer (urea) and other by-products of the poultry agro-industry. Strong negative effects on lettuce vegetative parameters were observed with the incorporation of poultry litter into soil.

Feathers bioprocessing by Bacillus sp. CL18 represents a technological approach for feathers management and recycling into valuable $\mathrm{N}$-rich fertilizers. Particularly, this appears to be the first report on utilization of a microbial FH for lettuce cultivation. FH could be a promising agricultural input when considering both the enormous amount of waste feathers and the area planted with lettuce in Brazil. In this regard, optimization of FH production and application, cost analysis, and the assessment of potential residual effects of FH fertilization for subsequent lettuce crop cycles are among the topics that merit further investigation. Additionally, these feather hydrolysates could be surveyed for hydroponic lettuce production.

Open Access This article is distributed under the terms of the Creative Commons Attribution 4.0 International License (http://creat ivecommons.org/licenses/by/4.0/), which permits unrestricted use, 
distribution, and reproduction in any medium, provided you give appropriate credit to the original author(s) and the source, provide a link to the Creative Commons license, and indicate if changes were made.

\section{References}

Alvarenga P, Mourinha C, Farto M, Santos T, Palma P, Sengo J, Morais M-C, Cunha-Queda C (2015) Sewage sludge, compost and other representative organic wastes as agricultural soil amendments: benefits versus limiting factors. Waste Manag 40:44-52. https:// doi.org/10.1016/j.wasman.2015.01.027

Baglieri A, Cadili V, Monterumici CM, Gennari M, Tabasso S, Montoneri E, Nardi S, Negre M (2014) Fertilization of bean plants with tomato plants hydrolysates. Effect on biomass production, chlorophyll content and N assimilation. Sci Hortic 176:194-199. https://doi.org/10.1016/j.scienta.2014.07.002

Bose A, Pathan S, Pathak K, Keharia H (2014) Keratinolytic protease production by Bacillus amyloliquefaciens $6 \mathrm{~B}$ using feather meal as substrate and application of feather hydrolysate as organic nitrogen input for agricultural soil. Waste Biomass Valor 5:595605. https://doi.org/10.1007/s12649-013-9272-5

Cantú RR, Aita C, Doneda A, Giacomini DA, Dessbesell A, Arenhardt M, Bastiani GG, Pujol SB, Rochette P, Chantigny MH, Giacomini SJ (2017) Alternatives to regular urea for abating $\mathrm{N}$ losses in lettuce production under sub-tropical climate. Biol Fertil Soils 53:589-599. https://doi.org/10.1007/s00374-017-1202-4

Castoldi G, Freiberger MB, Pivetta LA, Pivetta LG, Echer MM (2014) Alternative substrates in the production of lettuce seedlings and their productivity in the field. Rev Ciênc Agron 45:299-304. https ://doi.org/10.1590/S1806-66902014000200010

Choi J-M, Nelson PV (1996) Developing a slow-release nitrogen fertilizer from organic sources: II. Using poultry feathers. J Am Soc Hortic Sci 121:634-638

Colla G, Nardi S, Cardarelli M, Ertani A, Lucini L, Canaguier R, Rouphael Y (2015) Protein hydrolysates as biostimulants in horticulture. Sci Hortic 196:28-38. https://doi.org/10.1016/j.scien ta.2015.08.037

Cozzolino V, De Martino A, Nebbioso A, Di Meo V, Salluzzo A, Piccolo A (2016) Plant tolerance to mercury in a contaminated soil is enhanced by the combined effects of humic matter addition and inoculation with arbuscular mycorrhizal fungi. Environ Sci Pollut Res 23:11312-11322. https://doi.org/10.1007/s11356-016-6337-6

CQFS-RS, SC - Comissão de Quimíca e Fertilidade do Solo (2016) Manual de adubação e calagem para os estados do Rio Grande do Sul e Santa Catarina, 11th edn. Sociedade Brasileira de Ciência do Solo, Porto Alegre (in Portuguese)

De Oliveira CT, Pellenz L, Pereira JQ, Brandelli A, Daroit DJ (2016) Screening of bacteria for protease production and feather degradation. Waste Biomass Valor 7:447-453. https://doi.org/10.1007/ s12649-015-9464-2

Gagnon B, Berrouard S (1994) Effects of several organic fertilizers on growth of greenhouse tomato transplants. Can J Plant Sci 74:167-168. https://doi.org/10.4141/cjps94-035

Gaskell M, Smith R (2007) Nitrogen sources for organic vegetable crops. HortTechnology 17:431-441

Gousterova A, Nustorova M, Paskaleva D, Naydenov M, Neshev G, Vasileva-Tonkova E (2011) Assessment of feather hydrolysate from thermophilic actinomycetes for soil amendment and biological control application. Int J Environ Res 5:1065-1070. https ://doi.org/10.22059/IJER.2011.464

Gunes A, Inal A, Taskin MB, Sahin O, Kaya EC, Atakol A (2014) Effect of phosphorus-enriched biochar and poultry manure on growth and mineral composition of lettuce (Lactuca sativa L. cv.) grown in alkaline soil. Soil Use Manag 30:182-188. https://doi. org/10.1111/sum.12114

Gurav RG, Jadhav JP (2013) A novel source of biofertilizer from feather biomass for banana cultivation. Environ Sci Pollut Res 20:4532-4539. https://doi.org/10.1007/s11356-012-1405-z

Hadas A, Kautsky L (1994) Feather meal, a semi-slow-release nitrogen fertilizer for organic farming. Fert Res 38:165-170. https://doi. org/10.1007/BF00748776

Hartz TK, Johnstone PR (2006) Nitrogen availability from high-nitrogen-containing organic fertilizers. HortTechnology 16:39-42

Jain R, Jain A, Rawat N, Nair M, Gumashta R (2016) Feather hydrolysate from Streptomyces sampsonii GS 1322: a potential low cost soil amendment. J Biosci Bioeng 121:672-677. https://doi. org/10.1016/j.jbiosc.2015.11.003

Joardar JC, Rahman MM (2018) Poultry feather waste management and effects on plant growth. Int J Recycl Org Waste Agric 7:183-188. https://doi.org/10.1007/s40093-018-0204-z

Kim JM, Choi YM, Suh HJ (2005) Preparation of feather digests as fertilizer with Bacillus pumilus KHS-1. J Microbiol Biotechnol $15: 472-476$

Kumawat TK, Sharma A, Bhadauria S (2017) Chrysosporium queenslandicum: a potent keratinophilic fungus for keratinous waste degradation. Int J Recycl Org Waste Agric 6:143-148. https:// doi.org/10.1007/s40093-017-0162-X

Muñoz-Huerta RF, Guevara-Gonzalez RG, Contreras-Medina LM, Torres-Pacheco I, Prado-Olivarez J, Ocampo-Velazquez RV (2013) A review of methods for sensing the nitrogen status in plants: advantages, disadvantages and recent advances. Sensors 13:10823-10843. https://doi.org/10.3390/s130810823

Mushtaq M, Iqbal MK, Khalid A, Khan RA (2019) Humification of poultry waste and rice husk using additives and its application. Int J Recycl Org Waste Agric 8:15-22. https://doi.org/10.1007/ s40093-018-0224-8

Paul T, Halder SK, Das A, Bera S, Maity C, Mandal A, Das PS, Das Mohapatra PK, Pati BR, Mondal KC (2013) Exploitation of chicken feather waste as a plant growth promoting agent using keratinase producing novel isolate Paenibacillus woosongensis TKB2. Biocatal Agric Biotechnol 2:50-57. https://doi. org/10.1016/j.bcab.2012.10.001

Paul T, Das A, Mandal A, Halder SK, Das Mohapatra PK, Pati BR, Mondal KC (2014) Valorization of chicken feather waste for concomitant production of keratinase, oligopeptides and essential amino acids under submerged fermentation by Paenibacillus woosongensis TKB2. Waste Biomass Valor 5:575-584. https:// doi.org/10.1007/s12649-013-9267-2

Pereira EIP, Conz RF, Six J (2017) Nitrogen utilization and environmental losses in organic greenhouse lettuce amended with two distinct biochars. Sci Total Environ 598:1169-1176. https://doi. org/10.1016/j.scitotenv.2017.04.062

Rogeri DA, Ernani PR, Mantovani A, Lourenço KS (2016) Composition of poultry litter in Southern Brazil. Rev Bras Ciênc Solo 40:e0140697. https://doi.org/10.1590/18069657rbcs20140697

Sala FC, Costa CP (2012) Retrospective and trends of Brazilian lettuce crop. Hortic Bras 30:187-194. https://doi.org/10.1590/s0102 -05362012000200002 (in Portuguese)

Sobucki L, Ramos RF, Daroit DJ (2017) Protease production by the keratinolytic Bacillus sp. CL18 through feather bioprocessing. Environ Sci Pollut Res 24:23125-23132. https://doi.org/10.1007/ s11356-017-9876-6

Sorathiya LM, Fulsoundar AB, Tyagi KK, Patel MD, Singh RR (2014) Eco-friendly and modern methods of livestock waste recycling for enhancing farm profitability. Int J Recycl Org Waste Agric 3:50. https://doi.org/10.1007/s40093-014-0050-6

Tamreihao K, Devi LJ, Khunjamayum R, Mukherjee S, Ashem RS, Ningthoujam DS (2017) Biofertilizing potential of feather hydrolysate produced by indigenous keratinolytic Amycolatopsis 
sp. MBRL 40 for rice cultivation under field conditions. Biocatal Agric Biotechnol 10:317-320. https://doi.org/10.1016/j. bcab.2017.04.010

Thuriès L, Pansu M, Feller C, Herrmann P, Rémy J-C (2001) Kinetics of added organic matter decomposition in a Mediterranean sandy soil. Soil Biol Biochem 33:997-1010. https://doi.org/10.1016/ S0038-0717(01)00003-7

Yang D, Guo Z, Green ID, Xie D (2016) Effect of cadmium accumulation on mineral nutrient levels in vegetable crops: potential implications for human health. Environ Sci Pollut Res 23:1974419753. https://doi.org/10.1007/s11356-016-7186-Z

Publisher's Note Springer Nature remains neutral with regard to jurisdictional claims in published maps and institutional affiliations. 